\title{
2. Positioning women in their place
}

[T] he dominant world-view is entirely from a male perspective, a perspective that has assigned to masculinity those characteristics which serve rationality, truth-seeking, logic. Woman, and the feminine, are cast in this scenario as the antithesis, the negation, and most particularly as the Other. (Haste, 1993, p. 5)

\section{WOMEN'S PLACE}

In this book, we use 'place' as a metaphor to illustrate how women in science are excluded from the 'place' of scientific 'action' (Miller, 1986, p. 75). Even though we are now in the twenty-first century, Miller's metaphor remains apposite to show how some men, both consciously and unconsciously, have over many years drawn on notions of 'difference' and 'otherness' to position women in lower grades. Here, we provide a taste of what this means theoretically, focusing on the UK and the USA.

Although 'place' may be interpreted in a variety of ways associated with geographical location, 'place' also has 'an extraordinary range of metaphorical meanings' (Harvey, 1993, p. 4). We argue that 'knowing their place' and the manner in which women 'internalize such notions psychologically' contributes to the consistent positioning of women at the margins, and lower levels within science (ibid; see also Miller, 1986; Newman, 1995; Puwar, 2004). Women's 'place' in science and how far women progress (or not) within science careers assumes an established system of mutually understood hierarchies within scientific occupations. Our research interviews suggest that such hierarchies pervade the lives of women working in science, most of whom experience and reflect upon their 'place' at work on a daily basis. The women who participated in our study were keenly aware of the 'pecking order' among co-workers and were acutely conscious of their place and position within this order, reporting feelings of difference or 'otherness' regarding how they were placed in relation to male colleagues.

According to Harvey (1993), 'difference' and 'otherness' should be treated as 'something omnipresent' in an elaboration of space and place (pp. 3-4). We draw upon feminist debates about 'difference' and 'otherness' and suggest that both these concepts are utilized within science 
organizations to position women in a subordinate and disadvantageous 'place' compared with men. Women's 'place' in science separates them from the more 'influential' activities mainly undertaken by men (Miller, 1986, p. 75; Newman, 1995, p. 19; Puwar, 2004, p. 8). Arguably, despite over 40 years of equal opportunities legislation, in science the statement: 'It's a man's world' made by Janeway in 1971 remains relevant (p. 7).

The word 'place', like the word 'space', has connotations of separation and difference (Harvey, 1993). For Puwar (2004), 'space' refers to the reserved organizational 'places' where women and non-white workers are less welcome; their presence is noticed and incites opprobrium, as they are bodies 'out of place'. Puwar describes women and non-white workers who attain career roles more usually associated with men as 'space invaders' and a threat to the status quo (Puwar, 2004, p. 8). Sounding a cautiously positive note, however, Puwar notes that 'protected spaces can't be contained. They remain dynamic and open to other possibilities. Space is not a fixed entity' (Puwar, 2004, p. 1).

We also acknowledge in our analysis of interview texts, the importance of '[l]anguage [which contributes to] keeping women in their place' (Tannen, 1992, p. 241). The language of management, as of science, has been described as essentially masculine (Calás and Smircich, 1996; Collinson and Hearn, 1996; Tannen, 1992) and this causes difficulties for women seeking to alter and enhance their position within organizational settings. For example, conversational and managerial styles are interpreted differently depending on who is communicating with whom and, as Tannen (1992) observes: 'If a man appears forceful, logical, direct, masterful, and powerful, he enhances his value as a man. If a woman appears forceful, logical, direct, masterful, and powerful, she risks undercutting her value as a woman' (p. 241; see also Eagly and Carli, 2007).

Thus, women who attempt to adjust their styles by speaking more assertively may appear better to fit those models of masculinity that are associated with leadership and authority and it is possible that such women may command more respect at work. Equally likely, however, is the prospect that assertive women may be disliked and disparaged by coworkers as aggressive, pushy and unfeminine (Tannen, 1992, p. 239). So, as Tannen (2008) writes: 'Women in authority are subject to a double bind, a damned-if-you-do, damned-if-you-don't paradox. Society's expectations about how a woman should behave and how a person in authority should behave are at odds' (p. 126; see also Eagly and Carli, 2007). 


\section{FEMINIST PERSPECTIVES: DIFFERENCE AND GENDER}

The values and qualities ascribed to women and men and how they are interpreted by society are based on perceptions of gender. In this section, we review the feminist perspectives that give rise to how differences are perceived and the effect they have on how people ascribe the value of a difference.

Feminist debates about 'difference' began with a liberal feminist discourse dating from the eighteenth century with Mary Wollstonecraft's $A$ Vindication of the Rights of Woman (1792 [1999]), followed by John Stuart Mill's (1869 [2006]) 'The subjection of women', which influenced the suffragette movement. Liberal feminism became a force for emancipation that centred on notions of equality of access and opportunities (Schiebinger, 1999). In this view, it is hypothesized that if women were given the same access and opportunities as men, they would achieve equivalent career advancement. Fundamental to feminist liberal research agendas is the emphasis on gender stereotyping and sex segregation; they also highlight glass ceilings (or labyrinth[s]) that prevent women's progress to senior positions by blocking their way or sending them on circuitous routes where men tend to travel in a straight line (see Calás and Smircich, 1996; Eagly and Carli, 2007, p. 6). Cockburn (1991) describes equality of opportunities as 'breaking down barriers that prevent horizontal movement by women into non-traditional jobs, and removing those that confine women to the meanest jobs and prevent their vertical progress to different levels and locations in the hierarchy' (p. 46).

Though much criticized as being conceptualized around the situation of the privileged white middle class (arguably to the detriment of working class, ethnic minority and/or non-heterosexual women) liberal feminism has been the forerunner of much of the equal opportunities legislation in the UK and the USA. The reason for state alignment with a liberal feminist approach is possibly because this is regarded by governments as less threatening to capitalist economies (and as requiring less change from neoliberal agendas) than other forms of feminism might require (Gatrell and Swan, 2008) although Eisenstein (1984) argues that present legislation would not have taken place without the inclusion of more forceful feminist voices, particularly radical feminists. While legislation is far from being the complete answer, Acker (1998) suggests that little change will happen within organizations without it.

The UK's Equality Act (2010) states that there are nine protected characteristics to avoid discrimination and promote equality in the workplace: age; disability; gender reassignment; marriage and civil partnership; 
pregnancy and maternity; race; religion or belief; sex; and sexual orientation (p. 4). Equality in these contexts identifies difference, and aims to treat those who might be disadvantaged in such a way as to safeguard access to the same opportunities as more privileged groups. In theory, as a consequence of equal opportunities legislation, evidence of disadvantage may be challenged within a legal framework. However, the indications from the women we interviewed who suffered discrimination were that legal challenges were avoided: as in Gatrell's (2008) research, women sought a career, not an employment tribunal.

Within liberal feminist paradigms, the optimistic (though as yet unproven) view has been that equal opportunities may reduce disadvantage associated with difference and improve the situation of women, assuming that, '[i]f the facts are known, people will change' (Delamont, 2003, p. 9). Radical feminist perspectives locate gender differences as central and treat 'difference' as an 'alternative way of doing things, rather than as a deficit' (Haste, 1993, p. 7; also see Eisenstein, 1984). Radical feminist perspectives reject male forms of power and in their purest form advocate women-only communities (see Calás and Smircich, 1996; Eisenstein, 1984). 'Womancentred feminism', where women are 'placed' at the centre of the debate, is derived from the writings of lesbian feminists and illustrates the advantages for women if they are free from a commitment to men (Eisenstein, 1984, p. 48):

By virtue of their lack of sexual ties to men, and therefore of their freedom from conventional heterosexual commitments, especially marriage, lesbians were placed sociologically in a situation of great freedom . . . Thus, they could think radically and profoundly without reference to gender arrangements. (Eisenstein, 1984, p. 50)

Radical feminism celebrates fundamental biological experiences shared by many women (such as the potential for menstruation and childbirth), and positions these differences as defining women's superiority compared with men (Cronin, 1991; see also Calás and Smircich, 1996; Eisenstein, 1984; Haste, 1993). The emphasis on valuing feminine 'difference' is core to many 'diversity' initiatives (Gatrell and Swan, 2008) and is emphasized by Carol Gilligan (1982), who posits that women have essentially female values that influence their ways of thinking, feeling and behaving, and are undervalued by society's application of masculine standards and norms.

In contrast to radical feminism, socialist feminism minimizes differences between the sexes almost to the point of androgyny (Eisenstein, 1984). Socialist feminism arose out of challenging the continued inequality of women compared with men despite nearly 100 years of women fighting for 
equality. As such, it challenges the oppression of women and the power of men and contests the way women are constructed as subordinate to men in both public and private spheres. Oppression from capitalism originates in Marxist theories when work and social structure combine to subordinate working class men (Smith, 1974). According to Calás and Smircich (1996) socialist feminist theory brings together the best parts of Marxist theories (which do not adequately acknowledge women's situation) with psychoanalytic and radical feminism. Socialist feminism is thus closely linked with political and social action and considers that the oppression of women derives from both capitalism and patriarchy (Calás and Smircich, 1996; Eisenstein, 1984; Haste, 1993). Here, in accordance with a socialist feminist approach, we suggest that many differences between women and men relate to the social performance of gender and may be cultural (not biological) and that gendered behaviours are more likely be learned than inherent (Haste, 1993). As Wajcman (1998) observes: 'the values being ascribed to women originate in the historical subordination of women. The association of women with nurturance, warmth and intuition lies at the heart of traditional and oppressive conceptions of womanhood' (p. 60). In keeping with Wajcman's views, we argue here that women's lowered 'place' in science, compared with men, occurs as a consequence of organizational cultures and practices in science. A significant shift in attitudes towards women's position and intellectual value and potential is required within science if change is to be achieved.

Below, we argue that in science, men are positioned as dominant, with women positioned as 'different', not fitting into the masculinist ideal of creative scientific genius: men undertaking 'men's work' associate it with status and exclude women as 'other' (Davies and Thomas, 2002, p. 479; see also Hollway, 1996). Within science (and organizations more broadly), the theoretical 'differences' ascribed to women tend to be constructed as biological and inherent. Such supposed differences include a feminine aptitude for caring (partly due to women's capacity for reproduction) and apparently empathetic and intuitive personality traits (Haste, 1993; Gilligan, 1982; Noddings, 1984; Ruddick, 1989).

As a consequence, responsibilities to 'care for' (usually male) co-workers, and organizational systems often fall to women. 'Caring for' at work, across a variety of occupations, is often deemed to be 'low skilled' and is associated with 'low pay [and] insecurity' (Edwards and Wajcman, 2005, p. 38, citing Radin, 1996). In science, women's careers may stall as they are placed (and remain in) service roles supporting more senior men (Hewlett et al., 2008). This reflects inequalities of gender, race and class found in wider society where, "[w]omen find themselves either "serving" male bosses, or working in the "caring" industries in conditions that almost 
replicate their subordinate role at home' (Sims et al., 1993, p. 174; see also Hartmann, 1979).

Witz (1992) observes how in specialist settings (such as science, medicine and academia) women have historically been more likely than men to undertake 'semi-professional' roles involving support activities, effectively placing them in the 'role of handmaiden to male professionals' (p. 68; see also Fotaki, 2013; Ramsay and Letherby, 2006). Co-worker and line manager assumptions that care and empathy should come 'naturally' to women (Miller, 2005) are frequently invoked as a means of persuading female workers into such roles, even if this was not their original ambition (Ramsay and Letherby, 2006). Women in science are 'assigned', often by male line managers, tasks that men do not wish to undertake themselves, including caring and 'emotional work' (Harding, 1991, p. 47). Harding (1991) asserts that men are likely to work in 'caring' roles only if these are associated with prestige and command high fees (for example, psychiatry). It is well known that 'feminine' occupations concerned with caring and support (care worker, secretary) are poorly paid in comparison with roles more usually associated with production and masculinity (electrician, hospital consultant), perhaps due to associations with the unpaid work undertaken by women (especially mothers) in heterosexual households (Equalities Review, 2007). In relation to medicine, Code (1991) has illustrated how women's skills as a carer are discounted: despite medicine ostensibly being a caring profession, professionalization (especially in relation to top consultant jobs) often excludes women and pervades other branches of science:

[W]omen's efforts to achieve authoritative status in the medical profession are both symptomatic and symbolic of the suppression of female knowledge and expertise. Medicine is a peculiarly salient example, for it enlists caring and nurturing skills long associated with women's essential nature. Yet the professionalization of medicine, together with its establishment on a scientific footing, produced an exclusionary structure in which experientially based female skills had no place. (Code, 1991, p. 227)

In particular, notions of genius and expertise are associated with knowledge and masculinities (Battersby, 1989; Code, 1991). As Code (1991) contends, women have suffered intellectually because they have historically been excluded from opportunities to become scientists.

In our research, we argue strongly that the supposed suitability of women workers to undertake caring and/or support roles is related to social constructions of gender, rather than any biological feature of womanhood. Yet social and organizational assumptions that women are innately possessed of empathy, and a resultant desire and talent for undertaking care and 
support work, affects the manner in which employed women are treated (we argue, especially in scientific environments; see Harding, 1991). This is because science is expected to be 'dispassionate, disinterested, impartial, concerned with abstract principles and rules' and such characteristics are associated with men (Harding, 1991, p. 47). Social assumptions about women's supposedly caring and intuitive characteristics inevitably exclude them from being perceived as ideal workers in a context where rationality is valorized as the ideal. And while women in science may be viewed as inherently lacking capacity for logical thought process, men are presumed to be naturally imbued with rational and systemic minds. Perceptions of women as intuitive but not necessarily rational have become infiltrated into organizational life to the advantage of men but to the detriment of women. As Founier and Keleman (2001, p. 268) argue:

Organizational structures, cultures and everyday practices have all been shown to constitute the 'ideal employee' (and especially the ideal manager) as a disembodied and 'rational' figure, a figure that fits more closely with cultural images of masculinity than femininity (see Acker, 1990, 1992; Gherardi, 1995; Martin, 1989). Femininity, on the other hand, has tended to be associated with embodiment, emotions and sexuality; as such it is constituted as subordinate to 'male' rationality, and possibly as out of place in 'rational' organizations.

Hollway (1996) describes how men are positioned as dominant in the practices of management and science, and women (especially mothers) are positioned as different, as separate, as 'other' or, as we discuss in Chapter 6, perhaps more appropriately, as ' $\mathrm{m}[\mathrm{o}]$ ther' (see Cooper, 1992; Fotaki, 2011). Hollway (1996) points out that men undertaking 'men's work' associate it with status and exclude women: 'Where work is defined as men's work in the gendered division of labour, we find that it relies on the other of women's work to invest it with masculine prowess or status, and thus on the exclusion or subordination of women' (p. 30).

As we show in the tables below, logic and rationality are thus associated with masculinity and favoured in the science workplace to men's advantage. 'Other' characteristics such as experience, intuition, serving and caring, are constructed by men (and some women) as apparently 'feminine' (see Bend1, 2008, citing Cullen, 1994; Haste, 1993). Such characteristics are welcomed so long as they keep women in their subordinate 'place' at work, arguably mirroring women's historic 'place' at home where women are responsible for domestic and care agendas, as Janeway (1971) depicts. However, in the science workplace, assumptions about women's aptitude for taking supporting (rather than leading) roles contribute to the maintenance of the status quo whereby women's 'place' is in the background. Tables 2.1 and 2.2 illustrate how values and qualities that are highly valued 
Table 2.1 Values and qualities praised

\begin{tabular}{ll}
\hline Masculine & Feminine \\
\hline High self-esteem & Reserved \\
Less respect for rules & Conventional \\
Autonomous & Conservative \\
Driven and single minded & Serving and caring \\
Confident & Reticent \\
Socially poised & Modest \\
Independent & Quiet \\
Charming & Faithful \\
Rational & Intuitive \\
Knowledge & Experience \\
Adventurous & Reliable \\
Risk taking & Cautious \\
\hline
\end{tabular}

Sources: See Bendl (2008, citing Cullen, 1994); Haste (1993).

Table 2.2 Interpretations of qualities

\begin{tabular}{ll}
\hline Masculine & Feminine \\
\hline Firm & Stubborn \\
Decisive & Bossy \\
Intellectual & Frivolous \\
Ambitious & Aggressive \\
Stable & Unpredictable \\
Driven & Uncompromising \\
Successful & Pushy \\
Decision maker & Consultative \\
Logical & Emotional \\
\hline
\end{tabular}

Sources: See Bendl (2008, citing Cullen, 1994); Haste (1993).

in men are viewed more negatively when ascribed to women - traits associated with successful male leaders (or scientists) are perceived to be inappropriate and 'pushy' when exhibited by women workers.

\section{WOMEN IN A 'SERVING' IMAGE}

According to Prather (1971), one reason why women are attracted to certain roles is because they are frequently portrayed in a 'serving' image and women subconsciously imitate these roles: 'as serving others in the 
nurturing and caretaking roles such as mother, housewife, volunteer, or nurse. The origin of this image is the assumption that we innately, instinctively, or hormonally are adept at nurturing, sacrificing and caring for others' (pp. 16-17). Arguably, being portrayed in the image of servants in films perpetuates such images (Delamont, 2003). When women scientists are portrayed in popular fiction, they are rarely portrayed as leaders, as Flicker (2003) indicates: "The role of the professional "scientist" is reserved for men; women are represented in less than a fifth of these roles' (Flicker, 2003 , p. 316). Perhaps the lack of images of women as scientific leaders is unsurprising, given that few women were admitted onto science degree programmes prior to the 1960s (Dyhouse, 2006) and where they have succeeded in pursuing scientific careers, women are often written out of historical accounts:

The notorious scarcity of intellectually authoritative women imposes a subtle contract on women's resistance to paternalism. Historically, there are notably few exemplary 'female knowers': no female Newtons, Descartes, or Darwins (though now we have Barbara McClintock). Hence women commonly have access only at second hand to ideals of cognitive authority. (Dyhouse, 2006, p. 187)

Whether or not fictional and historical portrayals of women as support workers (rather than as leading scientists and doctors) may be cited as a cause of limited opportunities, it remains the case that women are encouraged to take on caring and serving but rarely leading roles in science. This perpetuation of the status quo reinforces and reproduces the stereotypical positioning of women scientists as subordinate and inferior compared with male scientists.

Simone de Beauvoir indicated nearly 70 years ago in The Second Sex (1949 [1997]) that 'woman' is described with reference to 'man' as being the 'incidental, the inessential, as opposed to the essential' and quoting the French political and social philosopher and rationalist Benda, in his Rapport d'Uriel: 'He is the Subject, he is the Absolute - she is the Other' (Beauvoir, 1949 [1997], p. 16, quoting Benda, 1946).

It is important to recognize that serving roles, such as supporting junior staff and preparing for accreditation, are critical to the way a laboratory works. Despite such caring and serving roles being the responsibility of scientists alongside their scientific work, undertaking such work is not valued in the same way as creative research. Serving and caring roles take women away from the more high-profile science and, even when performed well, do little to recommend a woman as a serious scientist.

Ironically, as we demonstrate later in this book, the supposedly feminine traits of supporting, serving and caring are viewed in science as positive 
characteristics only when displayed by women who understand, and remain in, their 'place' at work. Should women attempt to step out of this place, positioning themselves, for example, as creative scientific geniuses (as in the case of Susan Greenfield), they may be treated as immodest trespassers, usurping the more prestigious 'place' in science more usually reserved for men. Our research interviews demonstrate how the association of genius and 'knowledge' with masculinity (Code, 1991) affects the perceptions and positions of both women and men in science.

\section{WHY DO WOMEN REMAIN IN THEIR 'PLACE'?}

Why is it that women remain in their 'place', or why is it, as Smith (1987) states, that '[w]omen are complicit in the social practices of their silence' (p. 34)? Kate Millett (1970 [2000], cited in Eisenstein, 1984), similarly asks 'how was it possible for patriarchy to continue in a world in which women had education, access to financial resources and extensive civil and political rights, and were not visibly subject to forms of direct coercion?' (p. 6).

While the feminist movement has consistently challenged gendered inequities at work, it remains the case that many employed women experience inequities on a daily basis, yet continue in their jobs. One of many explanations as to why women might continue working even when conditions are unfair, is Jean Baker Miller's (1986) theory of dominant and subordinate groups. In Miller's view, when dominant groups (for example, male healthcare scientists) hold power over supporting or subordinate groups (in our example, female healthcare scientists) this becomes the 'norm' for both parties. In everyday situations such as the workplace, overt challenges to this norm from subordinate groups may cause disruption and tension, as dominant groups resist any threat to their comfortable position. In turn, subordinate workers may avoid direct confrontation in order to circumvent conflict (knowing, perhaps, that the consequences for them as the weaker party in disagreements may be harsh they might develop indirect ways for achieving their aims; see Gatrell, 2005, for example, where it is observed how women treated unfairly at work may leave, transferring their skills to new employers who offer better terms).

Miller (1986) indicates that those who are subordinate within (especially gendered) relationships may have an acute understanding of how dominant groups will react to different situations and are 'able to predict their reactions of pleasure and displeasure' (p. 10). Arguably, such knowledge leads women in subordinate positions (both in science and other occupations) to accommodate the requirements of senior colleagues in order to minimize workplace battles. 
Miller (1986) illustrates 'difference' in the behaviour of dominant and subordinate groups with regard to women and ethnic minority groups where the subordinate group is perceived by dominant group members as having certain characteristics 'more like children than adults - immaturity, weakness and helplessness' (p. 7). Dominant group members fail to recognize 'potential' in the subordinate group, who are excluded from manifesting characteristics that might challenge the dominant group (ibid.). Furthermore, 'Members of the dominant group do not understand why "they" [the subordinates] are so upset and angry' (Miller, 1986, p. 9).

According to Miller (1986), members of dominant groups consider those people in groups that they perceive as subordinate to be 'well-adjusted', but only provided they remain in their place. However, subordinate groups may be unfairly characterized as 'unusual' or even 'abnormal' if they seek to challenge the status quo. Hearn (1998) supports Miller's views and suggests that women and men are so used to living with gendered inequities that the opportunities for women to press for changes are limited.

Our interview data support these explanations for the consolidation of women's 'place' in the lower ranks of science. In the forthcoming chapters, we offer further explanations for women's endurance of their subordinate place, including in relation to the conflict with husbands/partners/children when women try to develop their careers.

We now provide short case studies to illustrate examples of two women geniuses and experts who have been marginalized compared with equivalent men in science and excluded from recognition: Rosalind Franklin in the 1950s and Susan Greenfield in the first decade of the twenty-first century. Both these women symbolize how women can be excluded from notions of genius and expertise.

\section{Rosalind Franklin}

Rosalind Franklin is an example of a significant exclusion of a female scientist from receiving due credit. Franklin was not recognized in her lifetime for her contribution to the discovery of the double helix of DNA, which gained a Nobel Prize for Crick, Watson and Wilkins in 1962. Although she died in 1958 from cancer at the early age of 37, she could have been awarded the Nobel Prize posthumously (but was not) as the rules excluding posthumous awards were introduced only in 1974. Franklin's contribution was, however, marginalized in the records of the discovery that merited the award (Piper, 1998; Sayre, 1975; Stent, 1980).

The account of Rosalind Franklin's exclusion from recognition was first recorded in 1968 in the book by Watson (1968 [1980]) when he foregrounded his and Crick's achievements. Maurice Wilkins (the third 
recipient of the Nobel Prize) is also often forgotten. Watson's account was critical of many contributors, of whom Franklin was just one. Aaron Klug, Franklin's last student, who received her papers after her death, wrote a paper to set the record straight, saying that Franklin was closer to discovering DNA than had been previously recorded (Klug, 1968 [1980]) but this account, like Franklin herself, has largely been ignored. In 1980, Stent (1980) republished Watson's book in a 'critical edition' together with various relevant papers including Klug's to present the discovery of DNA in context.

Rosalind Franklin had gone to work with Wilkins and clashed with him, apparently expecting to work as an equal but found that he expected her to work as his assistant. According to Piper (1998), Franklin's appointment was to conduct her own research in X-ray diffraction but although her position was confirmed in a letter of appointment, it was not made clear to Wilkins.

It seems that Watson considered that Franklin was invading the male 'place' occupied by Watson and his colleagues. Watson (1968 [1980]) makes several personal remarks in his book about Rosalind Franklin's clothes, her lack of lipstick and uses a familiarity in reporting by referring to her as 'Rosy', commenting: 'Momentarily I wondered how she would look if she took off her glasses and did something novel with her hair' (p. 45). Watson confesses to using some of her data without permission: 'By then it had been checked out with Rosy's precise measurements. Rosy of course, did not directly give us her data. For that matter, no-one at King's realized they were in our hands' (p. 105). One of the reviewers, André Lwoff (1968 [1980]), comments on this: 'It is a highly indirect gift, which might rather be considered a breach of faith' (p. 228).

Watson (1968 [1980]) records in an epilogue that, as Franklin had died, she had been unable to challenge the events described in his personal account. As though to make posthumous amends, Watson states, 'Since my initial impressions of her, both scientific and personal ... were often wrong, I want to say something here about her achievements' (p. 132). He then accepts the difficulties of being a woman in science at that time: '[We both [Watson and Crick] came to appreciate greatly her personal honesty and generosity, realizing years too late the struggles that the intelligent woman faces to be accepted by a scientific world which often regards women as mere diversions from serious thinking' (p. 133). Although he precedes this statement with a paragraph about her achievements, he omits to praise her for her scientific ability. The epilogue is a somewhat poor recompense for the lack of recognition of her science.

Franklin has been recognized, not with a Nobel Prize, but with two blue plaques: one outside her flat in London and one on the wall at King's 
College London 'commemorating all those who were involved in the DNA work: the four names - Rosalind's included - fit nicely in round the rim' (Piper, 1998, p. 154). She has also been recognized, but only since 2003, by the Royal Society, which now makes an annual 'Rosalind Franklin Award' of a medal and $£ 30000$ to 'an individual [woman] for an outstanding contribution to any area of natural science, engineering or technology' (Royal Society, 2017).

\section{Susan Greenfield}

The second case study illustrating how a female creative genius and expert has been discounted is of Susan Greenfield, the Fullerian Professor of Physiology and Comparative Anatomy at Oxford University, who heads a team of scientists researching the genetics of Parkinson's and Alzheimer's diseases. She has been Director of the Royal Institution of Great Britain (RI), the first female to be its director in its 204-year-old history. She is a Baroness, a CBE and member of the House of Lords as one of the "people's peers' appointed by then Prime Minister Tony Blair in 2000.

Susan Greenfield was born in 1950 in North London, the daughter of a Jewish father (an electrician) and non-Jewish mother (a dancer). She attended Godolphin and Latymer School, an independent school for girls, where she studied little science. Her family had little money and her father's brother paid her school fees (Franks, 2011). Greenfield studied philosophy and psychology at St Hilda's College in Oxford, obtained her doctorate in pharmacology, also at Oxford, and has many fellowships and honorary doctorates from universities worldwide. Together with this academic career, she has frequently appeared on television and has written several books with a popular appeal about the brain and its function. She is also a co-founder of two biotech companies that specialize in brain diseases. Although she describes herself as an atheist, she says that her Jewishness is important to her, describing herself as 'a secular Jew' (McCarthy and Spanner, 2000). Greenfield (2002b) has described in the press her own difficulties in her late twenties working in the masculinist world of science: 'It was about then I seem to recall, that I started feeling irritated, rather than simply thinking that it was part of my lot in life to have men - and it always was men - make comments such as, "You don't look like a scientist"".

Susan Greenfield's more recent high-profile exclusion was not being elected a Fellow of the Royal Society. Tim Radford (2004) records in The Guardian that Susan Greenfield, although proposed for the long list of 535 nominations, was not one of 32 fellows of the Royal Society elected in a usually confidential process. This was confirmed by the Royal Society, who commented: 'The Council considers that the breach of confidence may 
have had the effect of damaging the professional reputation of Baroness Greenfield'. The Royal Society is renowned for electing very few women Fellows and in 2017 only 144 of the 1512 current elected Fellows were women (9.5 per cent) (Royal Society, 2017). Radford (2004) writes: 'the only name on the list of 535 original candidates to be revealed is Susan Greenfield's. Significantly, the only name now known to be not on the final shortlist is hers'. Radford (2004) comments: 'high-quality science is not the only reason for election. Fellowship is open to those who have raised public understanding or appreciation of science, or rendered conspicuous service in the cause of science'. The Royal Society took the unusual step of confirming that Susan Greenfield had been nominated, as Colin Blackstock wrote in The Guardian:

A spokesman for the Royal Society refused to comment in detail on a story in today's Times Higher Education Supplement which says Lady Greenfield has been rejected, but told the Independent, 'The candidate in question was considered by the relevant sectional committees at the meetings in January and the decision was taken then that she, along with the majority of other candidates, would not be placed on the long-list for election this year. (Blackstock, 2004)

In follow-up articles, whilst some people supported Susan Greenfield's nomination, others went on record to say she would not be suitable. In a public statement Susan Greenfield responded: 'I do not understand how or why my nomination has been made public. I think it is a great pity that those who do not have the courage to identify themselves can make unsubstantiated criticisms both of my science and of my activities in public communication'. In 2017, Susan Greenfield remains excluded as a Fellow of the Royal Society (Royal Society, 2017).

Baroness Greenfield continues to attract controversy. She gave a speech in the House of Lords on the damaging implications of technology on neuroscience, and has since published a book Mind Change (2014), which warns of risks to the brain of overuse of the Internet and social media. Her views, however, have met with criticism from scientists and the media alike, saying that her views are not based on evidence and are misleading (see Bell et al., 2015; Chivers, 2014). Furthermore, following months of infighting, she lost her position as Director of Royal Institution following expensive renovations to the Royal Institution premises that she led on behalf of its Board. She threatened to sue on the grounds of discrimination but the case was settled out of court. The Royal Institute and Baroness Greenfield released a joint statement saying they had 'reached a full agreement as to the terms for Baroness Greenfield's departure from the post of director': 'The trustees also paid tribute to Greenfield's work at the RI and stated that "in light of recent press coverage, we wish to clarify that decisions 
regarding the recent refurbishment of the premises on Albemarle Street had support and approval of the governing council"' (Mair, 2010). The post of Director of the Royal Institution was abolished in 2010.

In conclusion, we propose (and will pursue this argument as we examine our data in Chapters 3-6), that women's place in science remains firmly set as secondary to that of equivalent men. While it is hoped that UK government initiatives such as Athena SWAN, and new 'game changing' programmes in the USA will effect change and enhance the situation of women in science (Hewlett et al., 2008), we argue that such plans may be challenging to implement while attitudes about women's 'place', in the second tier of science, continue to endure. 